\title{
THE CHALLENGES FOR THE IMPLEMENTATION OF A GENDER-ORIENTED APPROACH TO BUDGETING IN UKRAINE: WHAT CAN BE IMPROVED?
}

\author{
Anna Karpych ${ }^{1}$, Nataliia Miedviedkova²
}

\begin{abstract}
The purpose of this article is to identify the obstacles which emerge on the way of the implementation of a gender-oriented approach to budgeting in Ukraine and hinder the promotion of this approach within the public financial system as well as to give recommendations on the possible ways to eliminate them from Ukrainian public financial management. Methodology. The article is based on a review of existing academic literature and on the analysis of secondary sources (mainly, government and non-government reports and publications). The results of the research show that the main barriers for the application of a gender-oriented approach to budgeting in Ukraine are, among others, dominance of gender stereotypes, the lack of funds for gender initiatives, insufficient understanding of the relationship between gender equality and public policy, the low level of awareness of civil servants and officials regarding the policy of gender equality. The overview of the best international practices in the integration of gender aspects in budgeting helped authors identify prior tasks for ensuring effectiveness of a gender-oriented approach to budgeting in modern conditions. Based on the obtained findings, the recommendations were provided; they include the measures to reduce gender gaps and suggested methods for modification of a gender-oriented approach to budgeting. Research limitations/implications. The authors did not study the underlying reasons for the emerging problems for the application of a gender-oriented approach to budgeting. Also, the research was based only on the review and analysis of secondary sources, thus, primary data collection techniques were omitted. Practical implications. The findings are likely to be useful for researchers and public sector practitioners both in Ukraine and abroad to gain knowledge on the implementation of a genderoriented approach to budgeting. The developing countries may investigate the case of Ukraine and prepare for the similar challenges and problems adjusting the practice of implementation of a gender-oriented approach to budgeting according to their conditions and model of public management system. Value/originality. The article contributes to the discussion about the challenges for the effective implementation of a gender-oriented approach to budgeting in order to strengthen the public financial management in modern Ukraine.
\end{abstract}

Key words: gender budgeting, gender-oriented approach to budgeting, public financial management, governance, public sector, Ukraine.

JEL Classification: H60, H61, H72

\section{Introduction}

In the public financial management, the budget is a precise reflection of the needs of the different groups or individuals to whom it is designed and adopted. According to A. Wildavsky and N. Caiden (2001), the budget is a forecast of future events, while the budgeting process is a transformation of financial resources into human goals. At the same time, the effective assessment and balancing of the financial resources of the national, regional and local levels of the budgetary system are

\footnotetext{
Corresponding author:

${ }^{1}$ Taras Shevchenko National University of Kyiv, Ukraine.

E-mail: annakarpych@univ.net.ua

ORCID: https://orcid.org/0000-0001-5345-7299

${ }^{2}$ Taras Shevchenko National University of Kyiv, Ukraine.

E-mail: nsmedvedkova@gmail.com

ORCID: https://orcid.org/0000-0001-6359-561X
}

possible only by means of high-quality approaches to budgeting.

As the plans and priorities of government are reflected through the budgets, the sources of their revenues and items of budgetary expenditures are exactly the indicators which demonstrate the degree of social orientation of the state and loc al policies. It may be admitted that public budgeting is also a political process, but the interests of only certain categories of citizens should not be promoted when the state pursues 
a policy of guaranteeing equal rights and opportunities for different groups of the population.

There is evidence that a vital component of human rights is social equality between women and men. An academician of the National Academy of Sciences of Ukraine V. Heiets (2020) highlights the high significance of socialization as an instrument of state policy of Ukrainian socio-economic development. Equality in rights plays a substantial role in the development of society, domestic and international economy, the formation of humanity, as well as in building a progressive future with prosperous moral and psychological principles. Currently, in Ukraine, the key actor in the regulation of gender equality is the state government with its gender policy, where the leading role is given to budgetary policy.

A budget that is based on the principles of taking into account the needs of both women and men is often referred to as a "gender-oriented budget" ("gender budget", "gender-responsive budget"). The first gender-oriented budget was introduced and adopted in Australia in 1984. At present, about 90 countries around the world apply a gender-oriented approach to budgeting. Two decades ago, Ukraine also became among the countries that integrate the gender component in budgets.

Ukraine faced its first case of the implementation of a gender-oriented approach to budgeting in 2003, when the Women's Fund of the city of Kharkiv conducted the gender analysis of the city budget (years 1998-2001) (Taukesheva \& Daudova, 2018). The outcome for this analysis was a development and adoption of a targeted subprogramme "Development and support of women's entrepreneurship" which became a part of the Programme for Economic Development of of Kharkiv for years 2003-2005.

In 2011, the Representative Office of the Friedrich Ebert Foundation in Ukraine started the project titled as "Gender Budgeting at the Local Level". The implementation began from the city of Chernivtsi and Khmelnytskyi oblast (region).

From 2014 up to the end of 2020, a systemic work by the "Gender Budgeting in Ukraine" Project was being done in order to promote a gender-oriented approach to budgeting in Ukraine. The project was financed by the Swedish government and implemented by NIRAS Sweden and CPM International.

Currently, the UN Women project and the USAIDfunded DOBRE programme ("Decentralization Offering Better Results and Efficiency") partly propagate and facilitate the establishment of a genderoriented approach to budgeting in Ukraine.

Noteworthy to highlight that a gender-oriented approach to budgeting has become an element of the public finance reform in Ukraine ("Strategy for reforming public finances for years 2017-2020”). According to the Strategy (2017), "The integration of a gender-oriented approach into the budget process will increase the efficiency and quality of public services provided, taking into account the needs of social groups, including on the basis of gender, will increase the accountability of organizationsbeneficiaries of the budget assets as well as budget transparency" (translated from Ukrainian by authors).

Furthermore, since 2019, this budgeting practice has been officially entrenched by the decree of the Ministry of Finance of Ukraine in Methodical recommendations for the implementation and application of a genderoriented approach in the budget process.

Despite the support from the government, international organizations and active leaders who are willing to promote minor as well as radical changes, the path of integration a gender-oriented approach to budgeting into public financial management of Ukraine is not without barriers. Therefore, the research aim of this article is to illustrate the current problems of the implementation of a gender-oriented approach to budgeting in Ukraine and provide the recommendations on how to eliminate them from Ukrainian public financial management.

\section{Literature Review}

\subsection{The outline of public governance and management theories}

The gender-oriented approach to budgeting might be considered as a constituent unit in the public governance system of a state.

The meaning and definition of governance have been discussed by a number of authors from various fields. According to Daly (2003), governance is about change processes. The concept of public governance is not stable since the development of economic and social relations transforms the governance models and provokes the review of how the governance is defined and considered by politicians, scholars and the general public. There has been a change to governance where the authorities (governing units) are not considered the only actors in steering a country. Such transition in the comprehension of governance is reflected with different theories of public management.

Previously, governance was seen as the ability and capacity of government to develop policies and implement them (Kjaer, 2004). Therefore, according to the Traditional Public Management Theory, a top-down approach of governance and the power of authorities were dominant. Within the given approach, the influence of the civil society and private institutions was not considered. As a result, the term of governance was used interchangeably with government (state, regional and local authorities) while bureaucratic systems along with political and administrative dichotomy served as a theoretical basis (Xu et al., 2015). 
With the emergence of the New Public Management Theory (since 1980s), new meanings to public governance have been brought where the private sector and the society play a more significant role in the coordination of social life (Heywood, 1997). Still democracy was not a central issue according to the New Public Management Theory. The role of a citizen was rather as a customer not a participant in decisionmaking processes (Xu et al., 2015).

At the same time, the New Public Management Theory was based on the enterprise management model ("entrepreneurial" government) and could not be characterised as civil society-oriented (Guowen \& Shuangshuang, 2012; Xu et al., 2015). Therefore, the New Public Service Theory has been developed in order to increase democracy; it puts the public interests first, provides the foundations for social trusts (Guowen \& Shuangshuang, 2012).

The most recent theory called "the New Public Governance Theory" has risen to promote both democracy and efficiency within the public management as it is based on contractualism, integrity theory and collectivism while considers citizens as full actors in political and social life (Xu et al., 2015). At present, more and more people take part in decision making on both local and national level, thus boundaries between public and private sectors and the spheres of government have become vague (Kjaer, 2004; Newman, 2005).

Taking all this into consideration, the definition of governance provided by Kaufmann et al. (2010) can be considered the most holistic for the reason that the authors consider the governance as those traditions and institutions which influence the way the authority in a state is exercised. Today, it is considered that the concept of governance and public management process are equal as the former includes the latter and requires citizen involvement and participation (Kapucu et al., 2009).

It can be stated that the implementation of a genderoriented approach to budgeting depends on the public management model each country choses separately. For this reason, the consideration of this approach to budgeting within the context of public management theory may be noteworthy.

\subsection{The essence of a gender-oriented approach to budgeting and a research gap}

Considering a gender-oriented approach to budgeting, attention is to be paid to its origin in economic theory. This approach comes from the feminist branch of macroeconomics (Çagatay et al., 2000). At the same time, Çagatay et al. (2000) claim that the very existence of a gender-blind economic policy, which is an antipode to a gender-oriented one, has led to social changes that forced the integration of gender aspects into budgets.
A gender-oriented approach to budgeting includes an analysis of the budget in terms of how it reaches and impacts women and men, as well as girls and boys (Budlender, 2006).

An economist and sociologist D. Elson (1997) argues about gender neutrality in budgeting as "gender blindness", because in the process of budgeting the established social roles of women and men are usually ignored, and this can worsen the position of both genders within society. Neoliberal economic guidelines and negative effects on the socio-economic security of women in combination with feminist movements strengthened the implementation of a gender-oriented approach to budgeting as a practical key strategy for the integration of gender aspects in the economic policy of the state (O’Hagan \& Klatzer, 2018).

T. Koliada (2019) claims that the application of a gender-oriented approach optimizes the expenditure of budget resources by determining the level of demand among consumers of guaranteed public services received from the implementation of budget programmes.

Previous research has established that the most common challenges are monitoring and evaluation of the approved budget documents, prioritisation of gender aspects in reforms, the lack of specialists who would have the knowledge and skills necessary for gender analysis, the scarcity of sex-disaggregated data, and weak coordination between different stakeholders on the comprehensive integration of a gender approach into strategies and policies (Vatuliov, Klymenko \& Kuznetsov, 2020; Ostrishchenko \& Korniienko, 2015; Kyseliova, 2020). So far, however, there has been a limited number of publications devoted to the detailed study of these problems and, most importantly, - to the discussion of the possible solutions for them.

Therefore, this article attempts to address two research questions:

1) "What are the modern challenges and barriers to the implementation of gender-oriented approach to budgeting in Ukraine?"

2) "How might the existing obstacles be eliminated in order to promote the practice of gender-oriented approach to budgeting within public financial management of Ukraine?"

The investigation of the challenges for effective implementation of a gender-oriented approach to budgeting in Ukraine is crucial for an adequate reaction and development of preventing measures.

\section{Method}

To conduct the research, the ontology of internal realism was chosen because we adhere to the position that we cannot observe concepts directly but they do have implications in reality. The epistemology of our 
study is social constructivism where the qualitative methods were adopted for the investigation of the challenges for the implementation of a gender-oriented approach to budgeting in Ukraine.

The research presented in this article was based on the analysis of secondary data with the review of academic articles, governmental and non-governmental organizations sources.

\section{Results}

\subsection{The contributing factors to the effective implementation of a gender-oriented approach to budgeting in Ukraine}

Today, there is no single generally accepted effective model of a gender-oriented approach to budgeting in the world since different countries have their own specific socio-economic and politicalcultural conditions. Therefore, a gender-oriented approach to budgeting should be adapted for each state separately.

However, it is still possible to systematize factors which are common around the globe that contribute to the effective implementation of a gender-oriented approach to budgeting. According to Downes \& Scherie (2020), three areas can be identified where the main factors for the successful application of a gender-oriented approach to budgeting can fall in: (1) a strategic framework, (2) tools of implementation, and (3) an enabling environment.

As for the strategic framework, it is vital to mention the state policies, the strategic goals of a country, the legislative framework and the institutionalization of a gender-oriented approach to budgeting in order to ensure its systemic application.

Nowadays, there is a legislative framework which facilitates the promotion of gender equality in Ukraine (including through budgetary mechanisms), but it needs to be updated with new documents on this issue.

Considering Ukrainian strategic framework, it is necessary to highlight the Constitution of Ukraine, international treaties of Ukraine, the Laws of Ukraine "On Ensuring Equal Rights and Opportunities for Women and Men", "On the Principles of Preventing and Combating Discrimination in Ukraine", "On Preventing and Combating Domestic Violence", the State social programme for ensuring equal rights and opportunities for women and men for the period up to 2021 (approved by the order of the Cabinet of Ministers of Ukraine dated April 11, 2018 No. 273), the implementation of the Beijing Declaration adopted at the Fourth World Conference on Women on September 15, 1995, the UN Sustainable Development Goals, etc. However, special attention should be paid to the Methodical recommendations for the implementation and application of a gender-oriented approach in the budget process, which have been approved by the order of the Ministry of Finance of Ukraine in 2019.

The tools for implementation of a gender-oriented approach budgeting refer to gender budgetary initiatives. At the initial stage of budgeting, such tools measure how different policies can affect gender equality, and include gender equality analysis and ex ante gender impact assessment. Then this information is used in a gender equality needs assessment which identifies the main gender gaps in various policies and promotes a gender perspective in the allocation of public financial resources.

At the stage of consideration of draft budgets and their adoption, these tools involve a report on the gender budget and social audit of the budget. In turn, ex post assessments of gender impact, a gender approach in performance audits and expenditure reviews, and a systematic audit of gender equality are used in preparing the budget execution report.

In accordance with the Methodical Recommendations approved by the Ministry of Finance of Ukraine (2019), a gender-oriented approach to budgeting "... is advisable to carry out in the following sequence: to inspect the normative legal acts and other documents containing information on gender equality; to conduct gender analysis of budget programmes; to make decisions based on the results of gender analysis of budget programmes; to monitor gender-sensitive budget programmes" (translated from Ukrainian by authors).

The enabling environment for the application of a gender-oriented approach to budgeting includes the use of sex-disaggregated data, the training and capacity development programmes, guidelines and recommendations for the application of a genderoriented approach to budgeting, structured interaction with the general public, and the creation of an expert group to advise on the implementation of such budgeting. But the most important thing here might be the presence of supreme bodies of supervision and control over the implementation of a gender-oriented approach to budgeting, such as the supreme audit institute or parliament (Downes \& Scherie, 2020).

Considering Ukraine, it can be stated that public and non-governmental organizations, as well as the Ministry of Finance of Ukraine, support the implementation of a gender-oriented approach to budgeting at the local, regional and national levels. The situation with the available official sex-disaggregated statistics is also gradually improving (although, not very rapidly).

To conclude this section, it can be stated that today in Ukraine there are the factors for the effective use of a gender-oriented approach to budgeting, while it is extremely important that civil society supports gender budget initiatives and actively participates in the public and political life of the state. However, despite the 
existence of positive contributing factors, the path of the implementation of a gender-oriented approach to budgeting remains rather complicated and requires more support from the government.

\subsection{Why the integration of gender aspects into public budgeting is not straightforward}

It is important to note that the world is interested in the Ukrainian experience of introducing and applying a gender approach to the budget process.

In 2019, a GIZ (Deutsche Gesellschaft für Internationale Zusammenarbeit) study tour was held for representatives of such countries as Armenia, Georgia and Azerbaijan. At the same time, a genderoriented approach to budgeting in Ukraine faces certain barriers for its implementation.

In the British Council research (2018), it is stated that a common challenge for Eastern Partnership countries (Armenia, Georgia, Azerbaijan and Ukraine) is their Soviet past, which preserves gender inequality in cultural and creative industries, as well as a generation gap, and an outdated educational system that encourages a gender biased way of thinking. It may be added that such state of affairs is observed not only within mentioned industries.

The gender barrier is an obstacle that does not give an opportunity to achieve an equal position in the labour market despite the availability of high levels of education and abilities of both women and men. The terms "glass ceiling", "sticky floor", "glass basement" are used to denote gender obstacles in the labour market. The situation called the "sticky floor" happens when women, in contrast to men, stay longer in low positions, and the "glass ceiling" describes stereotypes that do not create noticeable barriers to advancement, but at the same time do not allow moving forward. Thus, women are stuck between the "glass ceiling" and the "sticky floor" and cannot earn a promotion and reach the top. The "glass basement" means that men get the most risky but highly paid jobs.

Currently in Ukraine, the main obstacles for the implementation of a gender-oriented approach to budgeting at national, regional and local levels refer to weaknesses which outweigh the contributing factors identified in the section 4.2 of this article (Figure 1).

Among other things, the following barriers are crucial to consider while implementing a gender-oriented approach to budgeting:

- the rejection of changes by civil servants and officials of local authorities (in contrast to active civic leaders) who are very reluctant to change the established approaches, procedures and formats when developing documents used in the budget process;

- the high staff turnover that leads to weakening of the viewpoints for previously made decisions;

- the weak coordination between all stakeholders on integrating a gender approach into strategies, policies, programmes, and projects (Kyseliova, 2020).

\subsection{The successful foreign practices for institutionalization of a gender-oriented approach to budgeting}

The world practice shows the effectiveness of three ways for institutionalization of a gender-oriented approach to budgeting:

1. The submission of reports on a gender-oriented approach to budgeting, which provide information on public policy, the amount of budget support and how gender inequalities between women and men are reflected in economic terms (Sweden, Australia and Canada).

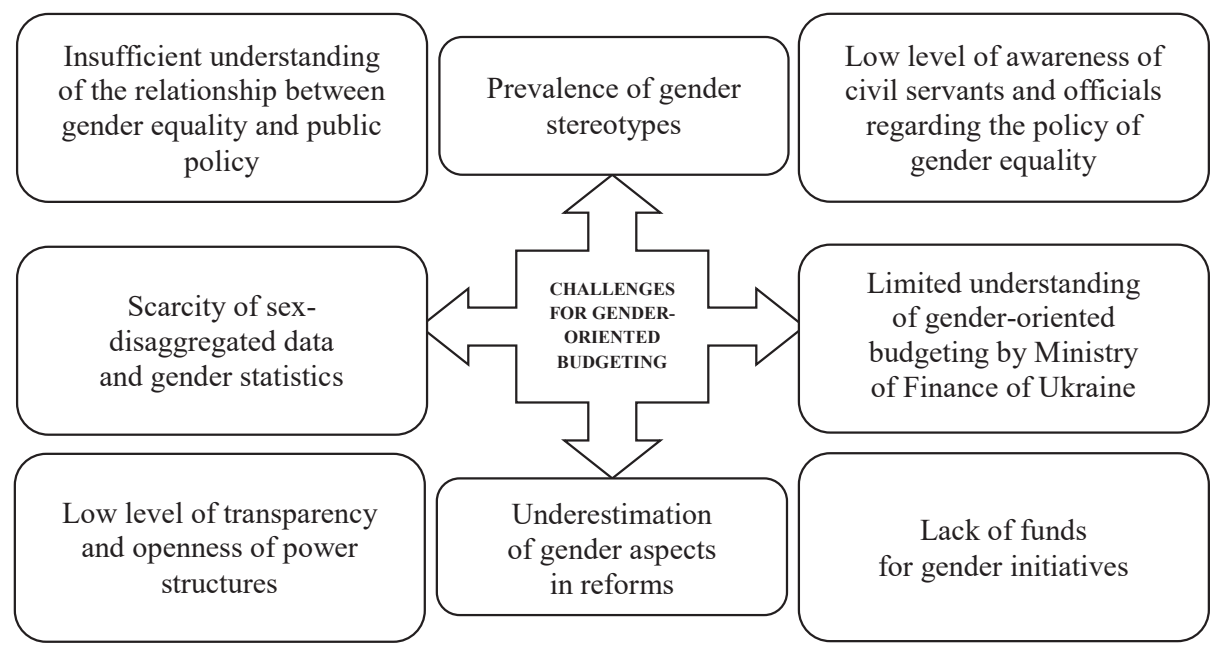

Figure 1. The main barriers for the implementation of a gender-oriented approach to budgeting in Ukraine

Source: developed by authors based on (Vatuliov, Klymenko \& Kuznetsov, 2020; Ostrishchenko \& Korniienko, 2015, Kyseliova, 2020; Khodakova, 2020) 
2. The promotion of a gender-oriented approach to budgeting through the application of laws, norms and regulations. Therefore, this budgeting is incorporated into the country's constitution, its budgetary legislation or administrative instructions (Austria, Albania, Canada, Belgium, Iceland).

3. The publication of a budget circular, which contains relevant gender-sensitive instructions for ministries and departments to submit budget requests for gender activities, goals, indicators (Finland, Albania, Spain).

Also, the foreign experience of a gender-oriented approach to budgeting provides the use of best practices, which have the following directions:

1. The creation of strategic documents to ensure an enabling environment for equal employment opportunities for women and men. In Kazakhstan, the Strategic Development Plan until 2025 aims to create favourable conditions for equal employment opportunities for women and men. Albania has taken important legal and policy steps to introduce gender budgeting at the central and local levels. In the context of public financial management reform, Albania has moved towards a medium-term system of expenditures and performance-based budgeting. The importance of a gender-oriented approach to budgeting for achieving gender equality in Albania is clearly outlined in the Public Financial Management Strategy (Kselo, 2020).

2. Government funding for capacity building. In Italy, political parties are required to allocate $5 \%$ of the government funding they receive on activities that promote women's political participation. Since 2009, public funds received by political parties in Ireland must be used for specific purposes, including promoting the participation of women and youth in political activities.

3. The consideration of gender aspects in the annual legislation. Regardless of where a gender-oriented approach to budgeting is introduced, it is accompanied by legal support measures. At the same time, the nature and scope of legislative provisions on a gender-oriented approach to budgeting varies from country to country. In Austria, the principle of achieving gender equality through the budget management system is enshrined in the Constitution, which has contributed to the development of a comprehensive a gender-oriented approach to budgeting and reporting system that has been integrated into the performance budgeting system. In Spain, the gender impact report is included in the annual budget bill, and in France, the annual budget bill contains an annex on the impact of fiscal policy on gender equality, as well as disaggregated budget expenditures (Kselo, 2020).

4. The introduction of gender-sensitive reporting. In Morocco, since 2014, under their new law, the budget takes into account goals, results and indicators of performance related to gender equality. In addition, the annual budget bill contains a gender report.
It provides a gender profile for each agency, an analysis of sectoral gender-related issues, and key genderrelated priorities, goals and achievements with ministries (Kselo, 2020).

Also, when developing new financial policies and measures, Pauel \& Ferrando (2020) advise authorities to pay attention to gender issues intensified in the context of financial and social crises caused by the COVID-19 pandemic:

1. Salaries and access to social protection. Due to persistent structural reasons, women earn less than men while also working part-time. Conversely, lower earnings and job insecurity weaken women's ability to cope with the economic shocks caused by the COVID-19 implications (Oritz-Ospina, 2018).

2. Unemployment and underemployment. Social distancing measures have a greater impact on women who have lost their jobs during this crisis more often than men. For example, in the UK, in sectors that have ceased operations to contain the spread of COVID-19, the major part of employees (mostly women) has lowpaid jobs (Close the Gap, 2020).

3. Healthcare. Among medical workers, administrative positions are predominantly held by men, which does not allow for the necessary changes that take into account gender aspects. Therefore, when planning financial activities for medical officials, it is important to represent and attract women, to ensure the validity of such activities.

4. Significant impact on women. As the COVID-19 pandemic shows, quarantine measures dramatically weaken the economic opportunities for women, thereby increasing the level of their poverty (UN Women, 2020).

\section{Discussion}

In accordance with the present results, previous studies have demonstrated that the main challenges for the implementation of a gender-oriented approach to budgeting in Ukraine lie within the weak coordination of different levels of government units, scarcity of official sex-disaggregated data and still lack of specialists who can support authorities in the introduction and application of this approach in the budget process.

Since budgeting can be considered a political process and not just a tool, it may help achieve social and gender equality (e.g., the redistribution of budget expenditures can reduce the gap between the positions of women and men in public life areas). However, these findings are not very encouraging in terms of the governmental support of institutionalization of a gender-oriented approach to budgeting. It is important to admit that Ukrainian legislation needs improvements and there should not be just recommendations but requirements to include gender aspects in the budgeting at all levels. 
Although women have been actively involved in economic and political life since the last century, in many countries as well as in Ukraine, they still have limited access to resources such as material goods, social contacts and their networks, income, natural resources, education and knowledge etc. In addition, cultural, ethnic and, to some extent, religious values, as well as the established division of labour in Ukrainian society have a significant impact on women's opportunities for self-realization and their realization as citizens and contributors to the whole society.

The government along with lawmakers plays a significant role in promoting gender equality as they develop and enact laws, set policies, and, what is also important, conduct educational and training activities to improve the situation of vulnerable and marginalized social groups.

This study has been able to demonstrate that a gender-oriented approach to budgeting is a powerful managerial approach that contributes to the implementation of gender equality policies, improving the quality and accessibility of services, and increasing the focus, efficiency and transparency of budget spending.

The analysis of the best foreign practices for the successful implementation of a gender-oriented approach to budgetary process allows us to identify the prior tasks for ensuring the effectiveness of a gender approach in modern conditions. Thus, the first task might be to strengthen political support for gender initiatives, which will make it possible to adjust programmes for the development of various sectors of the economy, taking into account the gender aspect and, as a result, to increase the efficiency of public financial management, improve the general economic and social situation in the country. There is also a need to coordinate the efforts of different departments to address the issues of transition to a gender-oriented approach to budgeting.

The findings demonstrate that social policy issues, along with gender inequality considerations should be included in the training programmes for public financial officials and managers.

Another important recommendations are the following: (1) to promote the active cooperation between the state and civil society in order to solve gender problems; (2) to conduct a gender analysis not only of expenditures, but also of budget revenues; (3) to raise gender awareness among major stakeholder groups; (4) to provide decent-paid jobs and equal opportunities for promotions for men and women; (5) to create an opportunity to implement changes that can protect women from severe shocks in the future; (6) to improve educational and training opportunities for women in order to move from precarious work to stable and better protected employment positions; (7) to ensure a gender-sensitive policy in the professional sphere, opening up new opportunities for women as entrepreneurs; (8) to expand the provision of social services that will provide women with more time for paid work and recreation.

In addition, it should be highlighted that gender inequality has been exacerbating during the current COVID-19 crisis all over the world, and if Ukrainian government do not take gender into account when preparing fiscal and financial responses to the pandemic, then the effectiveness of all efforts to mitigate the impact of the COVID-19 pandemic will be diminished.

In all the situations, the support from government institutions is an indispensable element of facilitating the implementation of this approach at all levels.

The study demonstrates that the way a genderoriented approach is implemented in Ukraine does not share the postulates presented with the New Public Governance Theory, however it has rather weak representation of such characteristics as democracy and efficiency within the public management.

It can be noted that the findings of the research may be somewhat limited by the chosen method for the study where only secondary sources were analysed. Therefore, further research should be undertaken to investigate the chosen challenges using primary data collection techniques and, on this basis, it might be possible to provide more sophisticated recommendations.

\section{Conclusions}

In this research, the aim was to identify and study the modern obstacles for the implementation of a genderoriented approach to budgeting in Ukraine and to suggest the possible solutions on how to prevent and overcome them.

The results of this study indicate that there are a number of issues which make it difficult to promote the practice of a gender-oriented approach to budgeting in Ukraine. Among the main challenges for the implementation of the studied approach are the existence of gender stereotypes, still a limited understanding of gender-oriented approach to budgeting by Ministry of Finance of Ukraine and the scarcity of sex-disaggregated data.

Our recommendations for the improvement of the implementation of a gender-oriented approach to budgeting in Ukraine consist of two parts: the first one includes measures to close gender gaps in society that have appeared as a result of stereotypes; the second part of the suggested ways is aimed at improving strategic framework, tools of implementation, and enabling environment for a gender approach to budgeting at national, regional and local levels.

To conclude, further work needs to be done to provide more ground recommendations for the implementation of a gender-oriented approach to budgeting in Ukraine. 


\section{References:}

Budlender, D. (2006). Expectations versus Realities in Gender-responsive Budget Initiatives. In Gender and Social Policy in a Global Context, pp. 322-339. doi: 10.1057/9780230625280_15

Çagatay, N., Keklik, M., Lal, R., Lang, J., \& UNDP (2000). Social Development and Poverty Elimination Division. Budgets as If People Mattered: Democratizing Macroeconomic Policies.

Close the Gap (2020). Disproportionate disruption: The impact of COVID-19 on women's labour market equality. Available at: https://scvo.scot/policy/evidence-library/2020-disproportionate-disruption-the-impact-of-covid19-on-womens-labour-market-equality

Daly, M. (2003). Governance and Social Policy. Journal of Social Policy, 32(1), 113-128. doi: 10.1017/ S0047279402006840

Downes, R., \& Scherie, N. (2020). Designing and implementing gender budgeting - a path to action. OECD Journal on Budgeting, 2020(2), 67-96. Available at: https://read.oecd-ilibrary.org/governance/designingand-implementing-gender-budgeting-a-path-to-action_689198fa-en

Elson, D. (1997). Gender-Neutral, Gender-Blind, or Gender-Sensitive Budgets?: Changing the Conceptual Framework to Include Women's Empowerment and the Economy of Care: pamphlet. Preparatory Country Mission to Integrate Gender into National Budgetary Policies and Procedures. London: Commonwealth Secretariat.

Genderna rivnist: mify, fakty ta derzhavna polityka: Posibnyk dlia narodnykh deputativ Ukrainy [Gender Equality: Myths, Facts and State Policy: A Guide for Deputies of Ukraine] (2020). Available at: https://www.ua.undp.org/ content/ukraine/uk/home/library/democratic_governance/gender-equality-handbook-for-mps.html (in Ukrainian)

Guowen, Zh., \& Shuangshuang, L. (2012). Ethical implication in the government governance reform. Proceedings of the 2012 International Conference on Public Management (ICPM-2012). 2012 International Conference on Public Management, China. doi: 10.2991/icpm.2012.36

Heiets, V. (2020). Sotsiolizatsiia ta sotsialna yakist yak instrumenty derzhavnoi polityky sotsialno-ekonomichnoho rozvytku [Socialization and social quality as instruments of state policy of socio-economic development]. Ekonomika Ukrainy, 10, 3-18. doi: 10.15407/economyukr.2020.10.003 (in Ukrainian)

Heywood, A. (1997). Politics (Macmillan Foundations) (1st ed.). Macmillan Press Ltd.

Kapucu, N., Yuldashev, F., \& Bakiev, E. (2009). Collaborative Public Management and Collaborative Governance: Conceptual Similarities and Differences. European Journal of Economic and Political Studies, 1, 39-60.

Kaufmann, D., Kraay, A., \& Mastruzzi, M. (2010). The worldwide governance indicators: Methodology and analytical issues (SSRN Scholarly Paper ID 1682130). Social Science Research Network. Available at: https://papers.ssrn.com/ abstract $=1682130$

Khodakova, S. (2020). Praktychnyi posibnyk dlia posadovykh osib orhaniv derzhavnoi vlady ta orhaniv mistsevoho samovriaduvannia "Henderne intehruvannia na mistsevomu rivni. Dosvid mist, shcho pryiednalysia do yevropeiskoi khartii rivnosti zhinok $i$ cholovikiv" [A practical guide for officials of public authorities and local governments "Gender integration at the local level. The experience of cities that have joined the European Charter for Equality between Women and Men”]. Available at: https://decentralization.gov.ua/uploads/library/file/607/GI_web.pdf (in Ukrainian)

Kjaer, A. M. (2004) Governance. Cambridge: Polity Press.

Koliada, T. (2019). Henderno-oriientovane biudzhetuvannia: sutnist ta perspektyvy zaprovadzhennia v Ukraini [Gender-oriented budgeting: essence and perspectives of implementation in Ukraine]. Ekonomichnij visnik. Seria: Finans. oblik, opodatkuvanna, 3, 80-88. doi: 10.33244/2617-5932.3.2019.80-88 (in Ukrainian)

Kselo, R. (2020). Genderno oriientovane biudzhetuvannia v zakonal pro biudzhet [Gender-oriented budgeting in laws on budgeting]. Suchasni tendentsii rozvytku i praktykt henderno oriientovanoho biudzhetuvannia na svitovomu, yevropeiskomu ta natsionalnomu rivniakh [Current trends of development and practices of gender budgeting at the global, European and national levels]. Kyiv: Vivario, pp. 22-32. (in Ukrainian)

Kyseliova, O. (2020). Henderno oriientovane biudzhetuvannia v Ukraini [Gender-oriented budgeting in Ukraine]. Suchasni tendentsii rozvytku $i$ praktykt henderno oriientovanoho biudzhetuvannia na svitovomu, yevropeiskomu ta natsionalnomu rivniakh [Current trends of development and practices of gender budgeting at the global, European and national levels]. Kyiv: Vivario, pp. 6-13. (in Ukrainian)

Newman, J. (2005). Remaking governance: Peoples, politics and the public sphere (1st ed.). Bristol University Press. doi: $10.2307 /$ j.ctt9qgqrt

O’Hagan, A., \& Klatzer, E. (2018). Gender Budgeting in Europe: Developments and Challenges. Springer.

Ortiz-Ospina, E., \& Roser, M. (2018). Economic inequality by gender. Our World in Data. Available at: https: //ourworldindata.org/economic-inequality-by-gender

Ostrishchenko, Yu. V., \& Korniienko, N. M. (2015). Henderne biudzhetuvannia na mistsevomu rivni yak instrument pidvyshchennia efektyvnosti vykorystannia biudzhetnykh koshtiv [Gender budgeting at the local level as a tool to increase the efficiency of budget funds]. Ekonomika rozvytku, 3(75), 12-27. (in Ukrainian)

Pauel, A. G., \& Ferrando, A. (2020). Stiikist hromad, henderna rivnist i henderno oriientovane biudzhetuvannia pid chas pandemii COVID-19 [Communities' resilience, gender equality and gender-oriented budgeting during the COVID-19 pandemic]. Suchasni tendentsii rozvytku i praktykt henderno oriientovanoho biudzhetuvannia na svitovomu, 
yevropeiskomu ta natsionalnomu rivniakh [Current trends of development and practices of gender budgeting at the global, European and national levels]. Kyiv: Vivario, pp. 105-113. (in Ukrainian)

Policy Brief: The Impact of COVID-19 on Women (2020) [Briefs; Policy papers]. UN Women Headquarters. Available at: https://asiapacific.unwomen.org/-/media/headquarters/attachments/sections/library/publications/ 2020/policy-brief-the-impact-of-covid-19-on-women-en.pdf?la=en\&vs=1406

Stan ta prosuvannia rivnykh mozhlyvostei dlia zhinok ta cholovikiv u kulturnykh ta kreatyvnykh industriiakh $\mathrm{v}$ Azerbaidzhani, Virmenii, Hruziii ta Ukraini [Status and Promotion of Equal Opportunities for Women and Men in Cultural and Creative Industries in Armenia, Azerbaijan, Georgia and Ukraine] (2018). Available at: https://www.britishcouncil.org.ua/sites/default/files/gender-equality-and-empowerment-ukr_0.pdf (in Ukrainian) Stratehiia reformuvannia upravlinnia derzhavnymy finansamy na 2017-2020 roky [Strategy for reforming public finances for years 2017-2020] (2017). Pro skhvalennia Stratehii reformuvannia upravlinnia derzhavnymy finansamy na 2017-2020 roky [On approval of Strategy for reforming public finances for years 2017-2020] (142-2017-p). Verkhovna Rada of Ukraine. Available at: https://zakon.rada.gov.ua/laws/show/142-2017$\% \mathrm{D} 1 \% 80 \#_{\mathrm{n} 9}$ (in Ukrainian)

Taukesheva, T. D., \& Daudova, G. V. (2018). Transformatsiia derzhavnykh finansiv: hendernyi biudzhet [Transformation of public finances: gender budget]. Aktualni problemy derzhavnoho upravlinnia, 1, 34-39. Available at: http://nbuv.gov.ua/UJRN/apdy_2018_1_7 (in Ukrainian)

Vatuliov, A., Klymenko, K., \& Kuznetsov, K. (2020). Uprovadzhennia hendernoho pidhodu v systemi upravlinnia derzhavnymy finansamy [Integrating gender approach into the public finance management system]. Finansy Ukrainy, 2, 55-81. doi: 10.33763/finukr2020.02.055 (in Ukrainian)

Wildavsky, A. B., \& Caiden, N. (2001). The New Politics of the Budgetary Process. Pearson.

Xu, R. Y., Sun, Q. G., \& Si, W. (2015). The Third Wave of Public Administration: The New Public Governance. Canadian Social Science, 11(7), 11-21. doi: 10.3968/7354 